\title{
RED CELL, PLASMA, AND BLOOD VOLUME IN HEALTHY WOMEN MEASURED BY RADIOCHROMIUM CELLL- LABELING AND HEMATOCRIT *
}

\author{
By E. BROWN, J. HOPPER, JR., J. L. HODGES, JR., B. BRADLEY, \\ R. WENNESLAND, $\dagger$ AND H. YAMAUCHI
}

\author{
(From the Department of Medicine and the Cardiovascular Research Institute, University of \\ California School of Medicine, San Francisco, and the Department of Statistics, \\ University of California, Berkeley, Calif.)
}

(Submitted for publication June 25, 1962 ; accepted August 15, 1962)

In a previous study of 201 healthy men (1), red cell volume ( $\mathrm{Vrbc}$ ) was measured by a modification of Sterling and Gray's radiochromium method (2), and whole blood and plasma volumes ( $\mathrm{Vwb}$ and $\mathrm{Vpl}$ ) were derived from venous hematocrits. The influence of factors other than body size on the variance of the data was studied, and standards for predicting normal volumes were derived. The present report describes a similar examination of 101 women.

\section{SUBJECTS AND METHODS}

The women, all of whom volunteered for study, werc actively employed as housewives, laboratory personnel, nurses, or office workers, and most were white (Table I). None were taking medications regularly or were subject to dietary control other than mild voluntary caloric restriction, and none were pregnant. Although some engaged in sports regularly, none were trained athletes. All had been living at sea level for at least a year. Cases of gross clinical obesity were not included. No subject was a regular blood donor, and none had given blood within 10 weeks. Health screening techniques included a medical history, physical examination, chest X-ray, and urinalysis. A hematocrit below 37 per cent, the limit of normal as defined by Wintrobe (3), caused exclusion of only one volunteer. In no subject was the arterial blood pressure over $140 \mathrm{~mm} \mathrm{Hg}$ systolic or $90 \mathrm{~mm} \mathrm{Hg}$ diastolic.

The method of labeling the autologous cells with $\mathrm{NaCr}^{51} \mathrm{O}_{4}$ and of determining their volume of distribution $\left(\mathrm{VCr}^{51}\right)$ was as described in the study on men $(1,4)$. Tests were performed before breakfast or, rarely, in the afternoon when lunch had been omitted. Subjects lay down for at least 30 minutes before the labeled cells were delivered and until sampling was completed no less than 35 minutes later. Precautions were taken to

\footnotetext{
* Supported by U. S. Public Health Service Grant H-1271 and by the Robert Harris Fund allocated by the Committee on Research of the University of California School of Medicine, San Francisco.

+ Research Fellow, American Heart Association.
}

prevent venous congestion during sampling. Hematocrit readings were not corrected for plasma trapping, and it was assumed that $\mathrm{Vwb}=\mathrm{VCr}^{51}$ (no allowance was made for a difference between the hematocrit of venous blood and that of the body as a whole) (1). Cell and plasma volumes were calculated by the formulas: $\mathrm{Vrhc}=$ $\mathrm{VCr}^{51} \times$ hematocrit; $\mathrm{Vpl}=\mathrm{VCr}^{51}-\mathrm{Vrbc}$.

The data were treated as outlined in the study of men (1). Regression equations were calculated by the method of least squares to describe the relations between volumes (Vrbc, Vpl, and Vwb) and body measurements (weight, height, weight and height combined, and surface area). The differences between the observed volumes ( Vrbc and Vpl) of each woman and the mean volumes found in women of the same height and weight were calculated by means of Equations 3 and 7, Table II. These differences, or "residuals," were used to analyze the influence of factors other than body size on the blood volumes.

\section{RESULTS}

\section{Volumes in relation to height and weight}

Table I summarizes the data. In Figure 1, each of the 101 subjects is represented according to her weight and height. In general, the relationship between weight and height was fairly uniform. Notable exceptions were four women weighing over $81 \mathrm{~kg}$, who proved to be 23 to 58 per cent overweight for height and age according to actuarial tables (5). The weight: height ratios of these subjects were more than 2 standard deviations above the mean of the ratios of the other 97 women. For this reason and because the series included so few large women, regression equations describing the relationships of the volumes to body measurements were prepared only for the 97 women weighing less than $74 \mathrm{~kg}$ (Table II). The bivariate regression equations described straight lines and the trivariate equations, planes without curvature (see Figures 1 to 4 ). The location of the regression plane for Vrbc in rela- 
RED CELL AND BLOOD VOLUME IN HEALTHY WOMEN : CR$^{51}$

TABLE I

Data in chronologic order from experiments on 101 healthy women

\begin{tabular}{|c|c|c|c|c|c|c|c|c|}
\hline \multirow[b]{2}{*}{ Subject * } & \multirow[b]{2}{*}{ Age } & \multirow[b]{2}{*}{ Height } & \multirow[b]{2}{*}{ Weight } & \multirow[b]{2}{*}{$\begin{array}{c}\text { Hemato- } \\
\text { crit } \dagger\end{array}$} & \multirow[b]{2}{*}{$\begin{array}{l}\text { Red cell } \\
\text { volumet }\end{array}$} & \multirow[b]{2}{*}{$\begin{array}{l}\text { Plasma } \\
\text { volume }\end{array}$} & \multicolumn{2}{|c|}{ Residual } \\
\hline & & & & & & & $\begin{array}{l}\text { Red cell } \\
\text { volume }\end{array}$ & $\begin{array}{l}\text { Plasma } \\
\text { volume }\end{array}$ \\
\hline & years & $\mathrm{cm}$ & $\mathrm{kg}$ & $\%$ & $L$ & $L$ & $m l$ & $m l$ \\
\hline M.Ho. & 45 & 169 & 58.0 & 39.1 & 1.48 & 2.31 & -10 & +150 \\
\hline M.Va. & 28 & 172 & 56.6 & 40.5 & 1.41 & 2.06 & -90 & -90 \\
\hline V.Sc. & 29 & 168 & 60.3 & 38.8 & 1.65 & 2.59 & +130 & +380 \\
\hline K.Ha. (J) & 40 & 144 & 51.8 & 38.0 & 1.15 & 1.86 & -70 & +80 \\
\hline A.Ma. & 33 & 162 & 53.0 & 41.9 & 1.44 & 2.00 & +70 & +20 \\
\hline P.Ca. & 28 & 175 & 58.7 & 37.2 & 1.40 & 2.34 & -150 & +110 \\
\hline M.Jo. & 44 & 173 & 69.5 & 39.4 & 1.66 & 2.54 & -30 & $\begin{array}{r}1 \\
+70\end{array}$ \\
\hline N.La. & 23 & 172 & 63.2 & 43.5 & 1.44 & 1.88 & -140 & -430 \\
\hline N.Hu. & 25 & 176 & 56.8 & 39.8 & 1.52 & 2.31 & -10 & +120 \\
\hline K.La. & 30 & 165 & 53.3 & 39.7 & 1.41 & 2.12 & +10 & +110 \\
\hline J.Ta. & 38 & 178 & 72.3 & 43.3 & 1.93 & 2.52 & +160 & -70 \\
\hline J.Mo. & 26 & 156 & 51.0 & 38.6 & 1.10 & 1.74 & -200 & -130 \\
\hline M.Iw. (J) & 22 & 156 & 52.6 & 41.7 & 1.33 & 1.85 & +10 & -60 \\
\hline J.Se. & 27 & 166 & 63.5 & 39.0 & 1.55 & 2.41 & 0 & +140 \\
\hline L.Bo. & 28 & 162 & 55.2 & 37.6 & 1.32 & 2.19 & -80 & +160 \\
\hline M.Sm. & 29 & 171 & 63.8 & 41.8 & 1.74 & 2.41 & +150 & $\begin{array}{r}+90 \\
\end{array}$ \\
\hline L.Fe. & 26 & 171 & 50.0 & 42.7 & 1.55 & 2.07 & $\begin{array}{r}160 \\
+160\end{array}$ & +90 \\
\hline $\mathrm{G} . \mathrm{Ov}$ & 20 & 164 & 58.3 & 41.2 & 1.43 & 2.04 & -30 & -80 \\
\hline S.Ri. & 31 & 163 & 54.2 & 40.4 & 1.43 & 2.11 & +40 & +100 \\
\hline E.Fi. & 21 & 171 & 62.0 & 39.7 & 1.35 & 2.05 & -220 & -220 \\
\hline J.Ke. & 22 & 161 & 53.4 & 39.8 & 1.38 & 2.08 & +10 & +100 \\
\hline S.Di. & 31 & 166 & 55.8 & 40.1 & 1.70 & 2.53 & +260 & +450 \\
\hline N.McL. & 25 & 166 & 53.5 & 39.9 & 1.41 & 2.13 & 0 & +110 \\
\hline J.We. & 23 & 171 & 57.0 & 40.7 & 1.70 & 2.48 & +210 & +330 \\
\hline P.Pr. & 28 & 173 & 60.6 & 42.2 & 1.48 & 2.02 & -80 & -240 \\
\hline F.Ca. & 21 & 160 & 51.7 & 37.7 & 1.14 & 1.88 & -200 & -50 \\
\hline L.MacI. & 20 & 171 & 54.9 & 41.6 & 1.48 & 2.07 & $\begin{array}{r}+20 \\
\end{array}$ & -30 \\
\hline M.Me. & 20 & 160 & 54.8 & 40.5 & 1.30 & 1.92 & -80 & -80 \\
\hline J.Pu. & 21 & 171 & 70.1 & 41.8 & 1.47 & 2.04 & -210 & -430 \\
\hline M.La. & 29 & 177 & 58.9 & 38.3 & 1.42 & 2.29 & -150 & +40 \\
\hline C.Bl. & 24 & 164 & 59.3 & 42.6 & 1.61 & 2.15 & +140 & 0 \\
\hline E.Ma. (sm) & 75 & 157 & 61.3 & 38.1 & 1.52 & 2.44 & +70 & +310 \\
\hline M.Go. ( $(\mathrm{sm})$ & 52 & 172 & 70.0 & 38.7 & 1.84 & 2.90 & +150 & +420 \\
\hline D.Li. & 27 & 168 & 63.0 & 38.6 & 1.70 & 2.72 & +140 & +450 \\
\hline R.Ad. & 28 & 164 & 54.4 & 40.7 & 1.45 & 2.11 & $\begin{array}{r}+50 \\
+5\end{array}$ & +80 \\
\hline P.Fo. & 44 & 161 & 55.6 & 38.9 & 1.49 & 2.33 & +90 & +300 \\
\hline J.St. & 24 & 157 & 68.1 & 41.1 & 1.40 & 2.01 & -150 & -290 \\
\hline M.Sc. & 41 & 159 & 49.5 & 40.4 & 1.60 & 2.36 & +300 & +500 \\
\hline S.We. $(\mathrm{sm})$ & 54 & 158 & 61.4 & 41.2 & 1.46 & 2.08 & 0 & -60 \\
\hline M.McG. (nm) & 54 & 173 & 57.7 & 42.4 & 1.64 & 2.21 & +120 & +20 \\
\hline A.Co. & 25 & 160 & 50.8 & 45.1 & 1.47 & 1.79 & +150 & -110 \\
\hline J.Be. & 22 & 159 & 51.0 & 44.9 & 1.37 & 1.69 & $\begin{array}{r}+50 \\
\end{array}$ & -210 \\
\hline V.Ma. & 39 & 159 & 49.0 & 42.1 & 1.23 & 1.69 & -60 & -160 \\
\hline B.Wi. & 28 & 168 & 57.6 & 41.8 & 1.62 & 2.27 & +140 & +130 \\
\hline P.Pe. & 25 & 163 & 51.7 & 45.7 & 1.37 & 1.63 & $\begin{array}{r}1+10 \\
+10\end{array}$ & -320 \\
\hline L.Fo. & 39 & 162 & 51.7 & 39.1 & 1.59 & 2.47 & +240 & +530 \\
\hline Z.Jo. (nm) & 50 & 159 & 53.9 & 44.2 & 1.62 & 2.03 & +260 & +60 \\
\hline M.Co. & 23 & 162 & 55.8 & 41.1 & 1.49 & 2.13 & +80 & +90 \\
\hline B.Pa. & 23 & 162 & 49.6 & 39.9 & 1.17 & 1.75 & -150 & -140 \\
\hline E.Jo. & 26 & 171 & 53.4 & 40.8 & 1.30 & 1.89 & -140 & -180 \\
\hline J.Ye. & 48 & 161 & 50.4 & 41.0 & 1.31 & 1.88 & -10 & -20 \\
\hline B.Re. & 27 & 164 & 54.3 & 41.6 & 1.56 & 2.18 & +160 & +150 \\
\hline K.McK. & 31 & 168 & 60.4 & 38.0 & 1.49 & 2.43 & -30 & +220 \\
\hline J.St. & 22 & 167 & 54.1 & 44.8 & 1.49 & 1.85 & +70 & -200 \\
\hline A.Mo. & 24 & 166 & 58.0 & 42.4 & 1.42 & 1.94 & -50 & -190 \\
\hline C.Ta. & 32 & 169 & 56.0 & 42.6 & 1.45 & 1.95 & -10 & -160 \\
\hline B.McK. & 31 & 161 & 53.2 & 42.8 & 1.47 & 1.96 & +110 & -10 \\
\hline N.Jo. (N) & 36 & 174 & 73.3 & 38.2 & 1.50 & 2.42 & -250 & -150 \\
\hline J.Ta. & 23 & 161 & 61.7 & 42.2 & 1.38 & 1.89 & -110 & -290 \\
\hline E.Fi. (sm) & 77 & 157 & 66.0 & 45.6 & 1.65 & 1.97 & +130 & -270 \\
\hline A.Ko. & 28 & 163 & 59.6 & 41.5 & 1.68 & 2.36 & +210 & +220 \\
\hline B.Gr. & 24 & 166 & 57.4 & 41.5 & 1.57 & 2.23 & $\begin{array}{r}+110 \\
+110\end{array}$ & +110 \\
\hline M.Bo. & 27 & 171 & 73.1 & 37.2 & 1.74 & 2.94 & $\begin{array}{r}+20 \\
\end{array}$ & +400 \\
\hline
\end{tabular}

* (J) Japanese, (N) Negro, (sm) spontaneous menopause, (nm) no menses, hysterectomy.

+ Uncorrected for trapped plasma and including buffy coat.

¥ Weight: height ratio exceptionally high. See Figures 1 to 4 . 
TABLE I-(Continued $)$

\begin{tabular}{|c|c|c|c|c|c|c|c|c|}
\hline \multirow[b]{2}{*}{ Subject * } & \multirow[b]{2}{*}{ Age } & \multirow[b]{2}{*}{ Height } & \multirow[b]{2}{*}{ Weight } & \multirow[b]{2}{*}{$\underset{\text { crit } \dagger}{\text { Hemato- }}$} & \multirow[b]{2}{*}{$\begin{array}{l}\text { Red cell } \\
\text { volume† }\end{array}$} & \multirow[b]{2}{*}{$\begin{array}{l}\text { Plasma } \\
\text { volume }\end{array}$} & \multicolumn{2}{|c|}{ Residual } \\
\hline & & & & & & & $\begin{array}{l}\text { Red cell } \\
\text { volume }\end{array}$ & $\begin{array}{l}\text { Plasma } \\
\text { volume }\end{array}$ \\
\hline & years & $\mathrm{cm}$ & $\mathrm{kg}$ & $\%$ & $L$ & $L$ & $m l$ & $m l$ \\
\hline B.Je. & 39 & 170 & 57.0 & 40.7 & 1.34 & 1.96 & -150 & -180 \\
\hline T.Fl. & 22 & 168 & 60.0 & 45.0 & 1.73 & 2.13 & +220 & -70 \\
\hline C.Re. & 28 & 171 & 63.2 & 42.2 & 1.76 & 2.40 & $\begin{array}{l}+180 \\
\end{array}$ & +100 \\
\hline L.Fl. & 43 & 161 & 56.5 & 42.6 & 1.49 & 2.00 & $\begin{array}{r}+80 \\
+80\end{array}$ & -50 \\
\hline W.LeR. & 29 & 172 & 64.3 & 41.0 & 1.34 & 1.93 & -270 & -410 \\
\hline J.Wy. & 28 & 178 & 67.7 & 42.7 & 1.66 & 2.22 & -40 & -250 \\
\hline L.Se. & 41 & 168 & 66.5 & 42.7 & 1.62 & 2.17 & +10 & -190 \\
\hline F.Ta. & 49 & 162 & $87.2 \ddagger$ & 41.2 & 1.85 & 2.65 & -10 & -150 \\
\hline J.Ew. & 16 & 173 & 63.4 & 42.2 & 1.61 & 2.20 & +10 & -130 \\
\hline P.Ju. & 36 & 165 & 54.8 & 41.1 & 1.37 & 1.97 & -50 & -80 \\
\hline M.Je. & 24 & 167 & 51.9 & 38.7 & 1.26 & 1.98 & -130 & -10 \\
\hline L.Gr. & 43 & 157 & 62.2 & 39.4 & 1.34 & 2.06 & -120 & -90 \\
\hline L. Br. & 36 & 167 & 58.6 & 42.1 & 1.60 & 2.20 & +110 & +40 \\
\hline D.Mi. & 25 & 176 & $81.4 \ddagger$ & 38.1 & 1.65 & 2.69 & -230 & -100 \\
\hline G.Va. & 23 & 156 & 44.8 & 37.8 & 1.00 & 1.64 & -210 & -80 \\
\hline T.Ya. (I) & 27 & 160 & 51.7 & 43.1 & 1.23 & 1.63 & -110 & -300 \\
\hline E.Pe. & 39 & 168 & 60.2 & 38.0 & 1.46 & 2.39 & -60 & +190 \\
\hline M.Da. $(\mathrm{sm})$ & 63 & 175 & $94.2 \ddagger$ & 40.9 & 1.86 & 2.69 & -200 & -400 \\
\hline E.Br. (nm) & 47 & 165 & $65.4^{+}$ & 41.9 & 1.75 & 2.43 & +180 & +130 \\
\hline P.Sc. & 22 & 159 & 59.9 & 38.9 & 1.36 & 2.12 & -100 & 0 \\
\hline N.Po. & 27 & 165 & $83.7 \ddagger$ & 38.3 & 1.44 & 2.31 & -390 & -430 \\
\hline M.Au. & 19 & 157 & $52.2^{+}$ & 39.4 & 1.26 & 1.94 & -60 & +30 \\
\hline C.Do. & 23 & 168 & 44.5 & 42.0 & 1.33 & 1.83 & +40 & +10 \\
\hline L.'Te. & 24 & 168 & 55.4 & 42.2 & 1.37 & 1.88 & -80 & -210 \\
\hline G.Gu. & 24 & 169 & 59.3 & 44.8 & 1.59 & 1.95 & +80 & -240 \\
\hline C.Sc. & 21 & 163 & 59.2 & 38.9 & 1.33 & 2.10 & -140 & -30 \\
\hline N.Ni. & 21 & 168 & 60.8 & 39.5 & 1.40 & 2.15 & -130 & -70 \\
\hline S.Ha. & 24 & 170 & 60.9 & 40.3 & 1.49 & 2.20 & -50 & -40 \\
\hline A.Mi. & 30 & 160 & 56.8 & 38.8 & 1.51 & 2.38 & +100 & +330 \\
\hline B.Mu. & 23 & 170 & 60.1 & 39.7 & 1.47 & 2.22 & -60 & 0 \\
\hline N.MacK. & 23 & 166 & 53.2 & 38.2 & 1.25 & 2.01 & -150 & -10 \\
\hline C.K1. & 23 & 155 & 49.4 & 40.3 & 0.99 & 1.46 & -280 & -370 \\
\hline V.Fr. & 31 & 171 & 67.4 & 40.5 & 1.76 & 2.59 & +120 & +190 \\
\hline B.Ha. & 27 & 173 & 61.3 & 44.3 & 1.68 & 2.11 & +110 & -170 \\
\hline V.Da. & 26 & 164 & 58.4 & 37.0 & 1.19 & 2.02 & -270 & -100 \\
\hline E.Ha. & 26 & 169 & 61.9 & 39.2 & 1.46 & 2.25 & -90 & 0 \\
\hline E.Mi. & 22 & 179 & 64.0 & 38.3 & 1.54 & 2.48 & -110 & +90 \\
\hline J.Ro. & 27 & 169 & 65.0 & 39.3 & 1.61 & 2.48 & +20 & +150 \\
\hline
\end{tabular}

tion to height and weight (Equation 3, Table II) is represented in Figure 1 by solid contour lines progressing from the lower left to the upper right of the chart, and the regression plane for $\mathrm{Vpl}$ by dotted contour lines.

\section{Analysis of residuals}

The residual Vrbc and $\mathrm{Vpl}$ of each subject are shown in Table I. A positive correlation $(\mathrm{r}=+$ 0.67 ) was found between the residuals for $\mathrm{Vrbc}$ and $\mathrm{Vpl}$.

Age. Table III shows the mean residuals of the subjects in various age groups. Comparison of mean residuals with their standard errors indicates that age had little effect on blood volume. There was a slight tendency for Vrbc and Vpl per unit of body size to be smaller in the younger than in the older women.
The menstrual cycle. Of the subjects whose menstrual periods were regular, 17 were in the fourth week of the cycle at the time of the measurement. They showed no evidence of hydremia. Mean residuals were $\mathrm{Vrbc}+2 \mathrm{ml}$ (SE 34) and $\mathrm{Vpl}-12 \mathrm{ml}$ (SE 52). In seven subjects, aged 47 to 77, who were no longer menstruating (see Table I), the mean residuals were positive: Vrbc $130 \mathrm{ml}$ (SE 51) and $\mathrm{Vpl} 87 \mathrm{ml}$ (SE 79). This group consisted of the six subjects aged 50 or more (Table III) and one additional woman aged 47.

Body build. In the group of 97 women used in calculating the regression equations, the mean ratio of weight in kilograms to height in centimeters was 0.350 (SD 0.032). Subjects whose ratios were beyond $\pm 1 \mathrm{SD}$ of the mean were chosen for analysis of residuals. The residuals tended to be 
negative at both ends of the distribution, although the differences were slight (Groups $\mathrm{A}$ and $\mathrm{C}$, Table IV). The tendency to negative values among subjects with high weight: height ratios is more evident after four menopausal women over the age of 50 (Group B, Table IV) are removed from consideration. The influence of excess weight is shown by Group D, Table IV. In all four of the women with exceptionally high weight: height ratios, the residuals for cells and plasma were negative.

\section{DISCUSSION}

Qualitatively, the results of this study bear many resemblances to our findings in men (1). As far as the regression lines and planes fitted by the method of least squares are concerned, the coefficients of variation again are smaller when the volumes are related to height and weight combined than when they are related to either measure alone, and are smaller for whole blood than for cells or plasma. Further, the coefficients of variation are exactly the same for the bivariate regression of volume to surface area (Du Bois' formula) and the trivariate regressions of volumes to height and weight combined (Table II).

Figure 1, a graphic expression of Equations 3 and 7 , Table II, also shows the range of weights and heights in the sampled female population. The regression equations derived from the data are not necessarily applicable to women whose weights and heights are outside the area covered by the

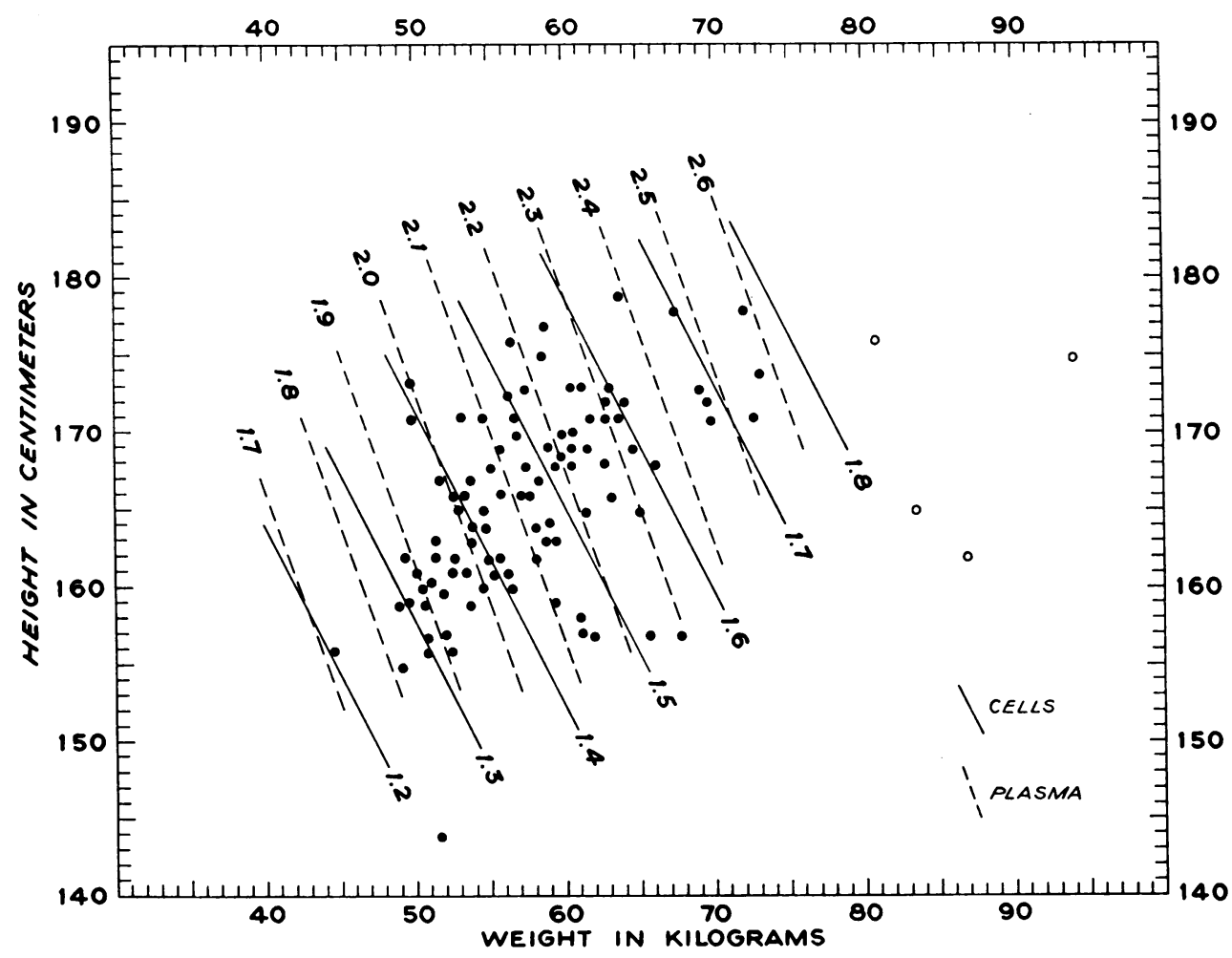

Fig. 1. Red cell and plasma volumes in relation to height and weight. Each circle represents one woman, plotted according to height and weight. Solid circles indicate women weighing less than $74 \mathrm{~kg}$ and open circles, women weighing over $81 \mathrm{~kg}$. The solid and dashed contour lines give the mean predicted red cell and plasma volumes ( $\mathrm{Vrbc}$ and $\mathrm{Vpl}$ ), respectively, to the nearest $0.1 \mathrm{~L}$, calculated from Equations 3 and 7, Table II. The mean predicted volumes of a woman $165 \mathrm{~cm}$ tall and weighing $60 \mathrm{~kg}$ are: $\mathrm{Vrbc}=1.45 \mathrm{~L}, \mathrm{Vpl}=2.13 \mathrm{~L}$, and $\mathrm{Vwb}=$ $3.58 \mathrm{~L}$. Values are uncorrected for trapped plasma and for differences between body hematocrit and venous hematocrit. Vrbc includes leukocytes and platelets.

The contour lines were constructed by introducing the successive mean values for $\mathrm{Vrbc}$ and $\mathrm{Vpl}$ in their respective regression equations (Equations 3 and 7, Table II) and computing the height for a given weight, or vice versa. 
TABLE II

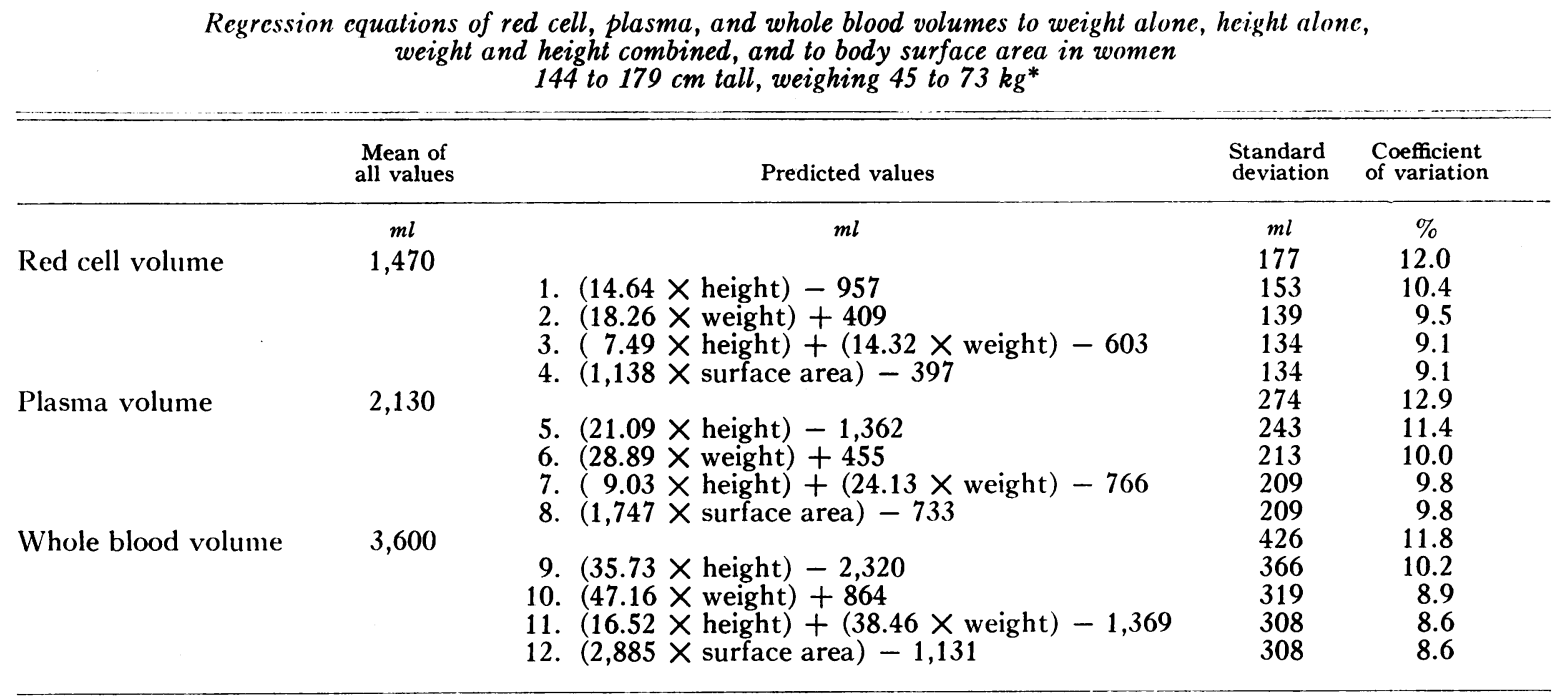

* Height in centimeters, weight in kilograms, and surface area in square meters as calculated from Du Bois' formula. Values are uncorrected for trapped plasma and for differences between body hematocrit and venous hematocrit.

solid circles. Therefore, in finding the expected cell or plasma volume of a given subject, it is desirable as well as convenient to locate her on the chart by weight and height and to make the prediction graphically. A subject of unusual weight or height, like the four who were excluded from our calculations, can be recognized easily when this procedure is followed.

The extensive data of Gibson and Evans (6) appeared to show that the amount of blood per unit of body size decreases with increasing size (weight, height, or surface area), especially in females. The present results, like our data for men, fail to confirm this for subjects whose weight: height ratios are in the common range. For women 144 to $179 \mathrm{~cm}$ tall, weighing 45 to $74 \mathrm{~kg}$, and with body surface areas of 1.4 to 1.9 square meters, sizes comparable to those of Gibson and
Evans' subjects, the fitted bivariate regression equations are linear (Figures 2 to 4 ). The graphs and regression equations of Samet, Fritts, Fishman, and Cournand (7), relating Vrbc and Vpl to weight and surface area for "hospital control" women and men in the same ranges of size as our subjects, show results in agreement with ours. For exceptionally heavy women, predictions based on weight alone tend to be too high (Figure 3 ). The data for our four heavy women are in best agreement with the remainder when the regression to surface area is used (Figure 4).

The average hematocrit of the women was 40.7 per cent (SD 2.1) and of the men studied under similar conditions (1), 45.2 per cent (SD 2.6). These values are lower than Wintrobe's (3) by 1.3 and 1.8 volumes per cent for women and men, respectively. Our blood samples were taken with

TABLE III

Influence of age on red cell and plasma volume

\begin{tabular}{|c|c|c|c|c|c|}
\hline \multirow[b]{2}{*}{ Age } & \multirow[b]{2}{*}{$\begin{array}{l}\text { Number of } \\
\text { women }\end{array}$} & \multicolumn{2}{|c|}{ Residual Vrbc } & \multicolumn{2}{|c|}{ Residual Vpl } \\
\hline & & Mean & $\begin{array}{c}\mathrm{SE} \\
\text { of mean }\end{array}$ & Mean & $\begin{array}{c}\mathrm{SE} \\
\text { of mean }\end{array}$ \\
\hline years & & $m l$ & $m l$ & $m l$ & $m l$ \\
\hline $20-24$ & 33 & -50 & 23 & -91 & 36 \\
\hline $25-29$ & 29 & 2 & 25 & 21 & 39 \\
\hline $30-39$ & 17 & 36 & 33 & 81 & 51 \\
\hline $40-49$ & 10 & 42 & 42 & 88 & 66 \\
\hline $50-59$ & 4 & 133 & 67 & 110 & 105 \\
\hline $60-77$ & 2 & 100 & 95 & 20 & 148 \\
\hline
\end{tabular}


TABLE IV

Influence of weight:height ratio on red cell and plasma volumes. Analysis of residuals in the 30 women with weight: height ratios beyond $\pm 1 S D$ from the mean

\begin{tabular}{|c|c|c|c|c|c|}
\hline \multirow[b]{2}{*}{ Group } & \multirow[b]{2}{*}{ Description } & \multicolumn{2}{|c|}{ Residual Vrbc } & \multicolumn{2}{|c|}{ Residual Vpl } \\
\hline & & Mean & $\underset{\text { of mean }}{\mathrm{SE}}$ & Mean & $\underset{\text { of }}{\mathrm{SE}}$ \\
\hline \multirow[t]{2}{*}{ A } & 15 women & $m l$ & $m l$ & $m l$ & $m l$ \\
\hline & $\begin{array}{l}\text { average age }=46 \text { years } \\
\text { weight }=<74 \mathrm{~kg} \\
\text { weight }: \text { height ratio }=>0.382\end{array}$ & -12 & 35 & -20 & 54 \\
\hline \multirow[t]{2}{*}{$\mathrm{B}^{*}$} & 11 women & & & & \\
\hline & $\begin{array}{l}\text { average age }=32 \text { years } \\
\text { weight }=<74 \mathrm{~kg} \\
\text { weight: height ratio }=>0.382\end{array}$ & -49 & 40 & -64 & 63 \\
\hline \multirow[t]{2}{*}{$\mathrm{C}$} & 11 women & & & & \\
\hline & $\begin{array}{l}\text { average age }=31 \text { years } \\
\text { weight }=<74 \mathrm{~kg} \\
\text { weight: height ratio }=<0.318\end{array}$ & -31 & 40 & -89 & 63 \\
\hline \multirow[t]{2}{*}{ I) } & 4 women & & & & \\
\hline & $\begin{array}{l}\text { average age }=41 \text { years } \\
\text { weight }=>81 \mathrm{~kg} \\
\text { weight }: \text { height ratio }=0.46-0.54\end{array}$ & -207 & 67 & -270 & 104 \\
\hline
\end{tabular}

* Group A minus 4 menopausal women aged 50 or more.

great care to avoid the effects of tourniquet stasis and only after the subject had rested in a horizontal position for an hour. The hematocrits would therefore be expected to be lower than those of samples taken from ambulatory subjects under ordinary conditions of collection $(4,8)$. The positive correlation between residuals of $\mathrm{Vrbc}$ and $\mathrm{Vpl}$ for women and men (1) shows that the he-

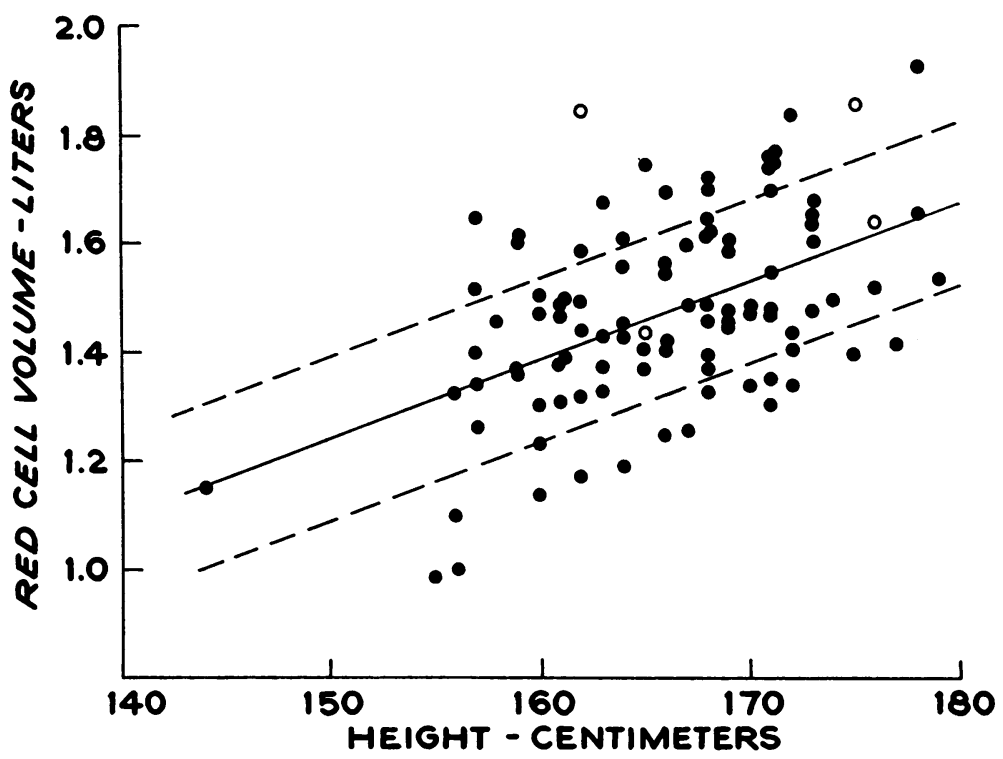

Fig. 2. Red cell volume in relation to height. The solid line is described by Equation 1, Table II, fitted to the data for the 97 women weighing less than $74 \mathrm{~kg}$ (solid circles). The dotted lines represent $\pm 1 \mathrm{SD}$ of the mean $\mathrm{Vrbc}$ for any given height. The open circles represent the four women with exceptionally large weight: height ratios. 


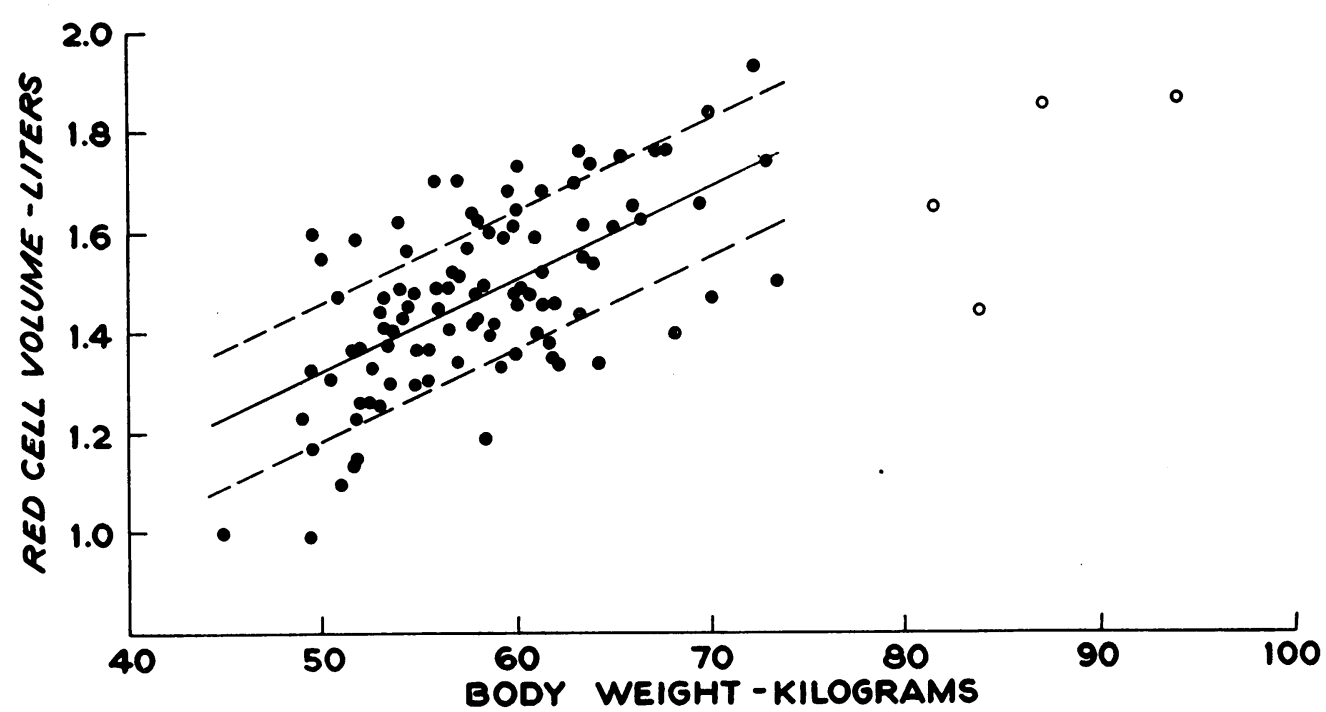

Fig. 3. Red cell volume in Relation to body weight. The solid line is described by Equation 2, Table II, fitted to the data for the 97 women weighing less than $74 \mathrm{~kg}$ (solid circles). The dotted lines represent $\pm 1 \mathrm{SD}$ of the mean Vrbc for any given weight. The open circles represent the four women with exceptionally large weight: height ratios.

matocrit is regulated within closer limits than the blood content per unit of body size. ${ }^{1}$ Thus, healthy persons with large cell volumes tend also to have large plasma volumes. This is in contrast to the situation in anemia and polycythemia, where de-

1 The results of replicated measurements, separated by various intervals of time, in 15 members of the male series led to the conclusion that most of the observed variation of $\mathrm{Vrbc}$ between individuals of the same size was biological rather than methodological $(1,4)$. ficiency or excess of cell mass is often balanced by reciprocal expansion or contraction of plasma (9). In this study, the coefficient of variation ( $\mathrm{SD}$ as per cent of the mean) was 5.1 per cent for hematocrit and 8.6 per cent for $\mathrm{Vwb}$ after regression to weight and height (Table II). Among the men, those with the highest hematocrits were apt to be short and heavy and those with the lowest hematocrits, tall and thin (1). The data for women showed no such relationship.

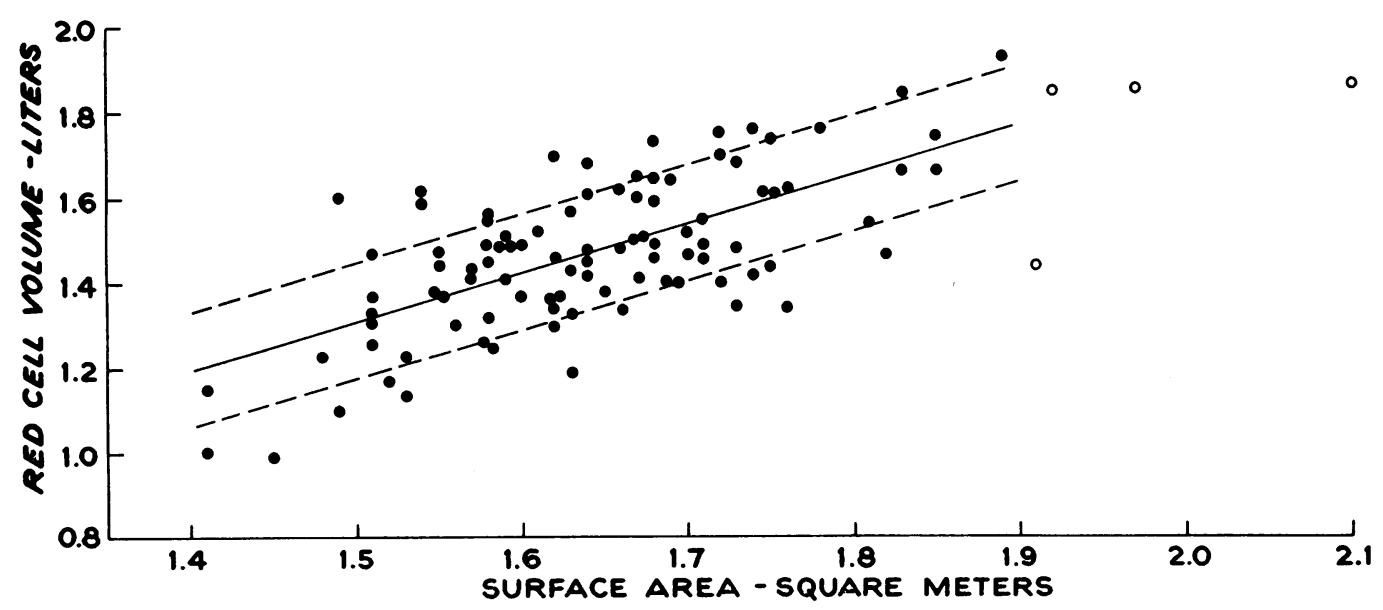

Fig. 4. Red cell. volume in relation to surface area as calculated from Du Bois' formula. The solid line is described by Equation 4, Table II, fitted to the data for the 97 women weighing less than $74 \mathrm{~kg}$ (solid circles). The dotted lines represent $\pm 1 \mathrm{SD}$ of the mean Vrbc for any given surface area. Open circles as in Figures 2 and 3. 
A comparison of the blood volumes of women and men ought only to be made within comparable ranges of heights and weights. Omission of the women under $160 \mathrm{~cm}$ in height and $54 \mathrm{~kg}$ in weight, as well as the four unusually heavy subjects, left 67 women who were within the ranges of heights and weights of the men previously studied (1). A residual value for $\mathrm{Vrbc}$ and $\mathrm{Vpl}$ was calculated for each of these women by means of the prediction equations derived from the data on men. ${ }^{2}$ The mean residuals were $\mathrm{Vrbc}-214 \mathrm{ml}$ (SE 23) and $\mathrm{Vpl}+85 \mathrm{ml}$ (SE 29). The difference in blood content between women and men of the same height and weight in our two studies thus averages only about $130 \mathrm{ml}$. In contrast, the compilation by Allen and associates (10) of data acquired by various techniques in Boston, Stockholm, and Taipei shows an average difference of $600 \mathrm{ml}$ between the blood volumes measured in nonpregnant women aged 20 to 50 and the predicted volumes for men of the same heights. weights, and ages.

The lower content of hemoglobin $(11,12)$, red cells $(13,14)$, and blood $(10,15-17)$ per unit of borly size in women than in men is usually attributed to the higher fat content of the female. It has been reported that the difference between the sexes becomes insignificant when Vrbc is related to lean body mass calculated from body water (14) or when blood volume is related to total body water (15). Blood volumes of women were in the range of those predicted for men when fat thickness and girth were included with height and weight as the bases of prediction (16). Data for both sexes fell on the same linear regression line relating blood volume, in milliliters per kilogram, to total body density in the study of Allen and coworkers (10). Huff and Feller's findings (13) for whole blood were similar, although at any given body density women tended to have lower cell volumes and higher plasma volumes in milliliters per kilogram than men. The latter suggests that sex-associated factors other than body density or fat content may influence the $\mathrm{Vrlyc}$ and relative cell volume.

To test whether differences in fat content could have accounted entirely for the sex differences

$\because$ V rbc $(\mathrm{ml})=(8.6 \times$ height $)+(18.6 \times$ weight $)-830$ $(\mathrm{SD} 190) . \mathrm{Vpl}(\mathrm{ml})=(19.9 \times$ height $)+(13.1 \times$ weight $)$ $-2,000$ (SD 240). found in our studies, we determined residual values for Vrbc and Vpl for the 67 women over 160 $\mathrm{cm}$ in height and $54 \mathrm{~kg}$ in weight, using the prediction equations for men as above, but multiplying the weight factor by 0.85 . This factor was chosen on the ground that it would overestimate slightly the difference in storage fat between women and men, which probably is about 12 to 13 per cent of body weight $(18,19)$. The mean residuals calculated on this basis were $\mathrm{Vrbc}-54$ $\mathrm{ml}$ (SE 23) and $\mathrm{Vpl}+20$ (SE 29). Although the correction achieved through this artifice is very good, the possibility still remains that factors other than body composition may play a role in determining the difference between the $\mathrm{Vrbc}$ of men and women. Drabkin has suggested that the loss of hemoglobin due to catamenia and gestation may contribute (12). The finding of consistently positive residuals and higher than average volumes in the older and nonmenstruating women of our series could be attributed to the cessation of catamenia. It is conceivable, however, that postmenopausal changes in the endocrine factors influencing erythropoiesis were responsible. Although the number of older people in both our studies was small, the tendency was for residuals to be negative in men and positive in women past the age of 50 .

\section{SUMMARY}

1. Red cell volume was measured with $\mathrm{Cr}^{51}$ labeled cells in 101 normally active women who had been screened for general health. Volumes of whole blood and of plasma were derived indirectly from venous hematocrits.

2. The data were collected and treated as described previously in a similar study on 201 healthy men. In the women, the degree of residual variation, after relation of the volumes to height, weight, height and weight combined, or to surface area, was about the same as that found in men. Trivariate regression equations relating volumes to height and weight combined were derived. A chart representing the equations graphically allows convenient prediction of red cell and plasma volumes for a woman of given height and weight.

3 . Sixty-seven women were of heights and weights such that they could be compared with the men previously studied. The red cell volume of the individual women was on the average 214 
$\mathrm{ml}$ smaller and the plasma volume $85 \mathrm{ml}$ larger than would be predicted for men of comparable height and weight.

\section{REFERENCES}

1. Wennesland, R., Brown, E., Hopper, J., Jr., Hodges, J. L., Jr., Guttentag, O. E., Scott, K. G., Tucker, I. N., and Bradley, B. Red cell, plasma and blood volume in healthy men measured by radiochromium $\left(\mathrm{Cr}^{51}\right)$ cell tagging and hematocrit: influence of age, somatotype and habits of physical activity on the variance after regression of volumes to height and weight combined. J. clin. Invest. 1959, 38, 1065.

2. Sterling, K., and Gray, S. J. Determination of the circulating red cell volume in man by radioactive chromium. J. clin. Invest. 1950, 29, 1614.

3. Wintrobe, M. M. Clinical Hematology, 5th ed. Philadelphia, Lea \& Febiger, 1961, p. 105.

4. Wennesland, R., Brown, E., Hopper, J., Jr., Scott, K. G., Hodges, J. L., Jr., and Bradley, B. Experiences with the radiochromium method for determination of red cell volume. Scand. J. clin. Lab. Invest. 1962, 14, 355.

5. Build and Blood Pressure, 1959, vols. 1 and 2. Compiled and published by Society of Actuaries, Chicago, 1959-1960.

6. Gibson, J. G., II, and Evans, W. A., Jr. Clinical studies of the blood volume. II. The relation of plasma and total blood to venous pressure, blood velocity rate, physical measurements, age and sex in ninety normal humans. J. clin. Invest. 1937, $16,317$.

7. Samet, P., Fritts, H. W., Jr., Fishman, A. P., and Cournand, A. The blood volume in heart disease. Medicine 1957, 36, 211.
8. Thompson, W. O., Thompson, P. K., and Dailey, M. E. The effect of posture upon the composition and volume of the blood in man. J. clin. Invest. 1928, 5, 573.

9. Brown, E., Hopper, J., Jr., and Wennesland, R. Blood volume and its regulation. Ann. Rev. Physiol. 1957, 19, 231.

10. Allen, T. H., Peng, M. T., Chen, K. P., Huang, T. F., Chang, C., and Fang, H. S. Prediction of blood volume and adiposity in man from body weight and cube of height. Metabolism 1956, 5, 328.

11. Sjöstrand, T. The total quantity of hemoglobin in man and its relation to age, sex, bodyweight and height. Acta physiol. scand. 1949, 18, 324.

12. Drabkin, D. L. Metabolism of the hemin chromoproteins. Physiol. Rev. 1951, 31, 345.

13. Huff, R. L., and Feller, D. D. Relation of circulating red cell volume to body density and obesity. J. clin. Invest. 1956, 35, 1.

14. Muldowney, F. P. The relationship of total red cell mass to lean body mass in man. Clin. Sci. 1957, 16, 163.

15. Zak, G. A., and Earle, D. P. Blood volume and body water in normal hospital subjects. J. Lab. clin. Med. 1957, 49, 504.

16. Hicks, D. A., Hope, A., Turnbull, A. L., and Verel, D. The estimation and prediction of normal blood volume. Clin. Sci. 1956, 15, 557.

17. Berlin, N. I., Hyde, G. M., Parsons, R. J., Lawrence, J. H., and Port, S. Blood volume of the normal female as determined with $\mathrm{P}^{32}$ labeled red blood cells. Proc. Soc. exp. Biol. (N. Y.) 1951, 76, 831.

18. Keys, A., and Brožek, J. Body fat in adult man. Physiol. Rev. 1953, 33, 245.

19. Johnston, L. C., and Bernstein, L. M. Body composition and oxygen consumption of overweight, normal and underweight women. J. Lab. clin. Med. 1955, 45, 109. 